\title{
Effect of Treating Chronic Hepatitis C Infection with Direct-Acting Antivirals on The Risk of Recurrence Hepatocellular Carcinoma
}

\author{
Enas Ahmed Reda Alkareemy ${ }^{1}$, Mohammed Zain El-Din Hafiz ${ }^{1}$, \\ Soumaia Ahmed Mohammed Ahmed ${ }^{2}$, Ahmed Saad Allah Abd el Aal Ahmed ${ }^{* 2}$ \\ ${ }^{1}$ Department of Internal Medicine, Faculty of Medicine, Assiut University, \\ ${ }^{2}$ Department of Internal Medicine, Faculty of Medicine, Aswan University
}

*Corresponding author: Ahmed Saad Allah Abd el Aal Ahmed, Mobile: (+20)1006818903, Email: dr.saadallah@yahoo.com

\begin{abstract}
Background: Hepatitis C virus (HCV) is a major global healthcare problem. The WHO estimates that up to $3 \%$ of the world's population has been infected with the virus, equating to more than 170 million individuals worldwide, with significant associated morbidity and mortality. Objective: The aim of this study was to detect effect of treating chronic hepatitis $\mathrm{C}$ infection with direct-acting antivirals on the risk of recurrence hepatocellular carcinoma.

Subjects and methods: This prospective study included a total of 150 patients with compensated chronic hepatitis $\mathrm{C}$ virus infection and 150 patients with compensated chronic hepatitis $\mathrm{C}$ virus infection with prior history of treated hepatocellular carcinoma by ablation, resection, chemoembolization or liver transplantation, attending at Viral Hepatitis Units, Departments of Internal Medicine, Assiut and Aswan University Hospitals. This study was conducted between December 2017 and December 2019. Results: The present study shows that 33.3\% of HCC had history of treatment with surgical resection, $46.7 \%$ had history of Radiofrequency ablation (RFA), $13.3 \%$ of Transarterial Chemoembolization (TACE) and 6.7\% with liver transplantation. There were highly significant differences between the two studied groups as regard ALT, total bilirubin, creatinine and AFP levels. There were no significant differences between the two studied groups as regard albumin, INR, platelets, total protein and WBCs. There were no significant differences between the studied groups as regard Hepatocellular carcinoma "occurrence or recurrence" and time needed for HCC to occur after direct-acting antiviral agents (DAAs).
\end{abstract}

Conclusion: It could be concluded that antiviral treatment should not be delayed in hepatocellular carcinoma patients in order to avoid further liver deterioration and extrahepatic complications of HCV.

Keywords: HCV, HCC, DAA, SVR, Hepatocellular carcinoma

\section{INTRODUCTION}

The development of safe and effective treatments for hepatitis $\mathrm{C}$ virus (HCV) infection has been a major concern for hepatologists in the last few decades. The era of interferon (IFN)-based treatment regimens was plagued with frequent, severe adverse events necessitating a strict follow-up and prompt management of complications, while sustained virologic response (SVR) rates were often not very high (1).

The last few years have seen a major step forward in the treatment of HCV with the introduction of alloral therapies. Direct-acting antiviral agents (DAAs) have since revolutionized the management of $\mathrm{HCV}$ patients, achieving high eradication rates with an excellent safety profile. The restrictions that IFN treatments imposed have been consigned to history and SVR rates have consistently exceeded $90 \%$, regardless of the chosen antiviral schedule. These unexpected, striking results led to the assumption that HCV could be virtually eradicated and on a global level, interrupting the natural history of the disease without incurring any severe side effects ${ }^{(2)}$.

Bearing in mind that chronic HCV infection is one of the main risk factors for the onset of hepatocellular carcinoma (HCC), lower rates of the latter's occurrence/recurrence were expected in the $\mathrm{HCV}$-eradicated population, whatever the stage of their liver disease was. Accordingly, as previously seen for patients successfully treated with IFN, the incidence rate of HCC dropped from 7.2/1000 person-years among patients with no SVR to $1.1 / 1000$ person-years among those who achieved a SVR ${ }^{(3)}$. Solid data on the long-term outcome of cirrhotic patients treated with these new regimens are still unavailable, however, and DAA registration trials did not distinguish between patients with and without a history of $\mathrm{HCC}^{(4)}$.

To date, controversial data have emerged on $\mathrm{HCC}$ occurrence/recurrence after $\mathrm{HCV}$ eradication with IFN-free treatment regimens. Most reports come from single-center, often retrospective, observational studies, with differences in patients' characteristics and length of follow-up. The picture consequently remains unclear for now, with a marked heterogeneity, even in terms of the control groups considered: some authors compared DAA-treated patients with those treated with IFN-based regimens; others compared them with untreated patients; and retrospective cohorts belonging to different eras were often involved. This might be partly attributable to several factors ${ }^{(5)}$.

For a start, HCC onset was not an endpoint in the initial DAA registration studies. Secondly, trials included patients with both chronic hepatitis $\mathrm{C}(\mathrm{CHC})$ and cirrhosis, with or without a history of HCC, and usually with a follow-up after treatment too short for the purpose of assessing HCC onset or recurrence. The incidence of HCC is also difficult to compare between patients given DAAs as opposed to IFN-based regimens because the former group also includes 
patients with decompensated cirrhosis, who are at higher risk of developing $\mathrm{HCC}{ }^{(6)}$.

The aim of this study was to detect Effect of treating chronic hepatitis $\mathrm{C}$ infection with direct-acting antivirals on the risk of recurrence hepatocellular carcinoma.

\section{PATIENTS AND METHODS}

This prospective study included a total of 150 patients with compensated chronic hepatitis $\mathrm{C}$ virus infection and 150 patients with compensated chronic hepatitis $\mathrm{C}$ virus infection with prior history of treated hepatocellular carcinoma by ablation, resection, chemoembolization or liver transplantation, attending at Viral Hepatitis Units, Departments of Internal Medicine, Assiut and Aswan University Hospitals. Written informed consent of all the subjects was obtained. This study was conducted between December 2017 and December 2019.

\section{Ethical approval:}

\section{Approval of the Aswan University academic and ethical committee was obtained.}

The included subjects were divided into two groups; Group (A) consisted of 150 patients with chronic HCV infection who were treated with direct acting antivirals and Group (B) consisted of 150 patients with chronic $\mathrm{HCV}$ infection with prior history of treated hepatocellular carcinoma who were treated with direct acting antivirals.

Sampling technique: This study was performed on Systematic random sampling.

\section{Inclusion criteria:}

1. Both men and women were included.

2. Age equal and above 18 years old.

3. Patients diagnosed with chronic HCV Child-Pugh class (A) liver cirrhosis.

4. Follow up duration of 12 months after treatment, at least.

5. Complete radiologic response in treated HCC patients [absence of residual tumor or complete necrosis according to European Association for the Study of the Liver (EASL) criteria, 2018] as well as absence of "non-characterized nodules" at imaging confirmed before starting DAA.

6. Treatment with an all-oral DAA combination, available in Egyptian markets.

\section{Exclusion criteria:}

1. Age less than 18 years.

2. Patients having end stage renal disease.

3. Patients with coexisting viral infection like hepatitis B surface antigen positive patients or HIV infection.

4. Patients with decompensated liver cirrhosis.

5. Follow up duration less than 12 months after treatment.
6. Patients with treated HCC but without radiologic complete response and/or presence of "noncharacterized nodules" before starting DAA.

7. Patients receiving interferon (IFN) as part of the antiviral regimen.

Clinical assessment: (a) History: complete history taking: age, sex, residency, occupation, smoking, presenting complaint, jaundice, itching, abdominal pain, weight loss, history of previous hepatic encephalopathy, history of previous antiviral treatment, history of previous bilharziasis or antibilharzial treatment and presence of comorbidities, such as diabetes mellitus or hypertension were evaluate. (b) Clinical examination: General and abdominal examination.

Laboratory investigations: Complete blood count (CBC), liver function tests, kidney function tests, prothrombin time, prothrombin concentration and INR, viral hepatitis markers (HBV surface antigen, HCV antibody), alpha fetoprotein (AFP), and quantitative HCV-RNA detection using real-time polymerase chain reaction (PCR).

Radiological assessment: Abdominal ultrasonography (US) and abdominal Contrast-enhanced "Triphasic" computed tomography (CT) scan in HCC patients.

Diagnosis of HCC is made on presence of nodular lesion with arterial enhancement in the arterial phase and rapid washout in the portal phase. According to American Association for the Study of Liver Disease (AASLD), every suspicious lesion in high-risk patients with suggestive US findings for HCC was evaluated. Furthermore, by multidetector CT scan or dynamic MRI with contrast, lesions that have the typical characters of $\mathrm{HCC}$ were identified, and the diagnosis of HCC was confirmed. Biopsy is not necessary for the diagnosis of $\mathrm{HCC}$ in a nodule greater than $2 \mathrm{~cm}$ at initial diagnosis and is compatible with $\mathrm{HCC}$ after one dynamic study.

\section{Statistical analysis}

Recorded data were analyzed using the statistical package for social sciences, version 20.0 (SPSS Inc., Chicago, Illinois, USA). Quantitative data were expressed as mean \pm standard deviation (SD). Qualitative data were expressed as frequency and percentage. Independentsamples t-test of significance was used when comparing between two means. Chi-square $\left(\mathrm{x}^{2}\right)$ test of significance was used in order to compare proportions between two qualitative parameters. The confidence interval was set to $95 \%$ and the margin of error accepted was set to $5 \%$. The p-value was considered significant as the following: P-value $<0.05$ was considered significant. P-value $<0.001$ was considered as highly significant. P-value $>0.05$ was considered insignificant. 
RESULTS

Group (A): patients with chronic HCV infection who were treated with direct acting antivirals. Group (B): patients with chronic HCV infection with prior history of treated hepatocellular carcinoma who were treated with direct acting antivirals.

Table (1): Studying of demographic data in between the studied groups:

\begin{tabular}{|c|c|c|c|c|c|c|}
\hline Variable & \multicolumn{2}{|c|}{ Group (A) $(n=150)$} & \multicolumn{2}{|c|}{$\begin{array}{l}\text { Group }(B) \\
(\mathbf{n}=150)\end{array}$} & t-test & $P$ value \\
\hline \multicolumn{7}{|l|}{ Age (years): } \\
\hline $\begin{array}{l}\text { Mean } \pm \text { SD } \\
\text { Range }\end{array}$ & \multicolumn{2}{|c|}{$\begin{array}{l}47.4 \pm 14.4 \\
(19-71)\end{array}$} & \multicolumn{2}{|c|}{$\begin{array}{l}51.45 \pm 14.9 \\
(19-72)\end{array}$} & 1.26 & $\begin{array}{l}0.208 \\
(\mathrm{NS}) \\
\end{array}$ \\
\hline \multicolumn{7}{|c|}{ BMI (Kg/m2): } \\
\hline $\begin{array}{l}\text { Mean } \pm \text { SD } \\
\text { Range }\end{array}$ & \multicolumn{2}{|c|}{$\begin{array}{l}26.3 \pm 1.3 \\
(23.4-29.6)\end{array}$} & \multicolumn{2}{|c|}{$\begin{array}{l}26.0 \pm 1.4 \\
(23.6-28.7)\end{array}$} & 1.22 & $\begin{array}{l}0.621 \\
(\mathrm{NS})\end{array}$ \\
\hline & No. & $\%$ & No. & $\%$ & $\chi^{2}$ & P value \\
\hline \multicolumn{7}{|l|}{ Gender: } \\
\hline $\begin{array}{l}\text { Women } \\
\text { Men }\end{array}$ & $\begin{array}{l}50 \\
100\end{array}$ & $\begin{array}{l}33.3 \\
66.7\end{array}$ & $\begin{array}{l}55 \\
95\end{array}$ & $\begin{array}{l}36.7 \\
63.3\end{array}$ & 0.214 & $\begin{array}{l}0.643 \\
\text { (NS) }\end{array}$ \\
\hline
\end{tabular}

$\chi^{2}$ for chi square test $\quad \mathrm{P}$ value is significant if $<0.05$

This table shows that there is no statistically significant difference between the two studied groups as regard age, BMI or gender.

Table (2): clinical and laboratory data in between the studied groups:

\begin{tabular}{|c|c|c|c|c|}
\hline Variable & $\begin{array}{l}\text { Group (A) } \\
(n=150)\end{array}$ & $\begin{array}{l}\text { Group (B) } \\
(n=150)\end{array}$ & t-test & $P$ value \\
\hline \multicolumn{5}{|c|}{$\operatorname{Albumin}(\mathrm{g} / \mathrm{L})$} \\
\hline $\begin{array}{l}\text { Mean } \pm \text { SD } \\
\text { Range }\end{array}$ & $\begin{array}{l}3.82 \pm 0.75 \\
1.8-4.8\end{array}$ & $\begin{array}{l}3.73 \pm 0.68 \\
1.9-4.8\end{array}$ & 1.08 & 0.277 \\
\hline \multicolumn{5}{|l|}{$\operatorname{ALT}(\mathrm{U} / \mathrm{L})$} \\
\hline $\begin{array}{l}\text { Mean } \pm \text { SD } \\
\text { Range }\end{array}$ & $\begin{array}{l}21.64 \pm 3.95 \\
16-86\end{array}$ & $\begin{array}{l}23.64 \pm 4.88 \\
18-90\end{array}$ & 3.90 & $\begin{array}{l}<0.001 \\
\text { (HS) }\end{array}$ \\
\hline \multicolumn{5}{|l|}{ AST (U/L) } \\
\hline $\begin{array}{l}\text { Mean } \pm \text { SD } \\
\text { Range }\end{array}$ & $\begin{array}{l}64 \pm 13.37 \\
24-91\end{array}$ & $\begin{array}{l}65.1 \pm 11.9 \\
25-97\end{array}$ & 0.752 & 0.452 \\
\hline \multicolumn{5}{|c|}{ Creatinine: $(\mu \mathrm{mol} / \mathrm{L})$} \\
\hline $\begin{array}{l}\text { Mean } \pm \text { SD } \\
\text { Range }\end{array}$ & $\begin{array}{l}2.0 \pm 0.31 \\
1.91-3.4\end{array}$ & $\begin{array}{l}2.2 \pm 0.35 \\
2.1-3.4\end{array}$ & 5.23 & $\begin{array}{l}<0.001 \\
\text { (HS) }\end{array}$ \\
\hline \multicolumn{5}{|c|}{ Hemoglobin: $(\mathrm{g} / \mathrm{dl})$} \\
\hline $\begin{array}{l}\text { Mean } \pm \text { SD } \\
\text { Range }\end{array}$ & $\begin{array}{l}9.87 \pm 2.51 \\
4.1-13.2\end{array}$ & $\begin{array}{l}9.87 \pm 2.51 \\
4.1-13.2\end{array}$ & 0.0 & $\begin{array}{l}1 \\
(\mathrm{NS})\end{array}$ \\
\hline \multicolumn{5}{|l|}{ INR: } \\
\hline $\begin{array}{l}\text { Mean } \pm \text { SD } \\
\text { Range }\end{array}$ & $\begin{array}{l}2.62 \pm 0.66 \\
1.6-3.9\end{array}$ & $\begin{array}{l}2.64 \pm 0.62 \\
1.6-3.9\end{array}$ & 0.135 & $\begin{array}{l}0.893 \\
\text { (NS) }\end{array}$ \\
\hline \multicolumn{5}{|c|}{ Total bilirubin $(\mu \mathrm{mol} / \mathrm{L})$} \\
\hline $\begin{array}{l}\text { Mean } \pm \text { SD } \\
\text { Range }\end{array}$ & $\begin{array}{l}2.81 \pm 0.19 \\
0.4-8.5 \\
\end{array}$ & $\begin{array}{l}4.58 \pm 1.53 \\
3.6-7.5 \\
\end{array}$ & 14.06 & $\begin{array}{l}<0.001 \\
\text { (HS) }\end{array}$ \\
\hline \multicolumn{5}{|c|}{ Alfa fetoprotein: $(\mathrm{ng} / \mathrm{mL})$} \\
\hline $\begin{array}{l}\text { Mean } \pm \text { SD } \\
\text { Range }\end{array}$ & $\begin{array}{l}8.1 \pm 1.3 \\
(4.8-16.0)\end{array}$ & $\begin{array}{l}17.3 \pm 2.3 \\
(5.6-58.9)\end{array}$ & 4.8 & $\begin{array}{l}\text { 0.041 } \\
\text { (S) }\end{array}$ \\
\hline \multicolumn{5}{|l|}{ WBCs *10 ${ }^{3}$ : } \\
\hline $\begin{array}{l}\text { Mean } \pm \text { SD } \\
\text { Range }\end{array}$ & $\begin{array}{l}6.84 \pm 1.55 \\
4.1-9.7\end{array}$ & $\begin{array}{l}6.84 \pm 1.55 \\
4.1-9.7\end{array}$ & 0.0 & $\begin{array}{l}1 \\
\text { (NS) }\end{array}$ \\
\hline
\end{tabular}

* = for Mann Whitney test

This table shows that there is highly significant difference between the two studied groups as regard ALT total bilirubin and creatinine levels; also there is significant difference between the studied groups as regard AFP while there is no significant difference between the two studied groups as regard albumin, INR and WBCs. 
Table (3): Type of DAA among the studied cases:

\begin{tabular}{|c|c|c|c|c|c|c|}
\hline \multirow[t]{2}{*}{ Variable } & \multicolumn{2}{|c|}{$\operatorname{Group}(A)(n=150)$} & \multicolumn{2}{|c|}{$\begin{array}{l}\text { Group }(B) \\
(n=150)\end{array}$} & \multirow[t]{2}{*}{$\chi^{2}$} & \multirow[t]{2}{*}{ p-value } \\
\hline & No. & $\%$ & No. & $\%$ & & \\
\hline \multicolumn{7}{|c|}{ SOF/DCV: } \\
\hline Yes & 50 & 33.3 & 51 & 34.0 & \multirow{2}{*}{0.0149} & \multirow{2}{*}{0.902} \\
\hline No & 100 & 66.7 & 99 & 66.0 & & \\
\hline \multicolumn{7}{|c|}{ SOF/LDV: } \\
\hline Yes & 55 & 36.7 & 57 & 38.0 & \multirow{2}{*}{0.057} & \multirow{2}{*}{0.811} \\
\hline No & 95 & 63.3 & 93 & 62.0 & & \\
\hline \multicolumn{7}{|c|}{ OBV/PTV/r: } \\
\hline Yes & 25 & 16.7 & 24 & 16.0 & \multirow{2}{*}{0.024} & \multirow{2}{*}{0.875} \\
\hline No & 125 & 83.3 & 126 & 84.0 & & \\
\hline \multicolumn{7}{|c|}{ SOF/VEL: } \\
\hline Yes & 20 & 13.3 & 18 & 12.0 & \multirow{2}{*}{0.120} & \multirow{2}{*}{0.728} \\
\hline No & 130 & 86.7 & 132 & 88.8 & & \\
\hline
\end{tabular}

This table shows that there is no significant difference between the studied groups as regard DAA used.

Table (4): Chronic diseases among the studied groups:

\begin{tabular}{|c|c|c|c|c|c|c|}
\hline \multirow[t]{2}{*}{ Variable } & \multicolumn{2}{|c|}{ Group $(A)(n=150)$} & \multicolumn{2}{|c|}{$\begin{array}{l}\text { Group (B) } \\
(\mathbf{n}=150)\end{array}$} & \multirow[t]{2}{*}{$\chi^{2}$} & \multirow[t]{2}{*}{ p-value } \\
\hline & No. & $\%$ & No. & $\%$ & & \\
\hline \multicolumn{7}{|l|}{ Diabetes: } \\
\hline Yes & 71 & 47.3 & 73 & 48.7 & \multirow{2}{*}{0.053} & \multirow{2}{*}{0.817} \\
\hline No & 79 & 52.7 & 77 & 51.3 & & \\
\hline \multicolumn{7}{|c|}{ Dyslipidemia : } \\
\hline Yes & 60 & 40.0 & 64 & 42.7 & \multirow{2}{*}{0.219} & \multirow{2}{*}{0.639} \\
\hline No & 90 & 60.0 & 86 & 57.3 & & \\
\hline \multicolumn{7}{|c|}{ Fatty liver: } \\
\hline Yes & 15 & 10.0 & 18 & 12.0 & \multirow{2}{*}{0.306} & \multirow{2}{*}{0.579} \\
\hline No & 135 & 90.0 & 132 & 88.8 & & \\
\hline \multicolumn{7}{|c|}{ Hypertension: } \\
\hline Yes & 49 & 32.6 & 50 & 33.3 & \multirow{2}{*}{0.0991} & \multirow{2}{*}{0.911} \\
\hline No & 101 & 67.4 & 100 & 66.7 & & \\
\hline
\end{tabular}

This table shows that there is no significant difference between the studied groups as regard chronic diseases.

Table (5): Relation between type of DAA and HCC development:

\begin{tabular}{|c|c|c|c|c|c|c|}
\hline \multirow[t]{2}{*}{ Variable } & \multicolumn{2}{|c|}{$\begin{array}{l}\text { Cases developed HCC } \\
\mathrm{N}=7\end{array}$} & \multicolumn{2}{|c|}{$\begin{array}{l}\text { cases didn't develop } \\
\mathrm{HCC}, \mathrm{N}=293\end{array}$} & \multirow[t]{2}{*}{$\chi^{2}$} & \multirow[t]{2}{*}{ p-value } \\
\hline & No. & $\%$ & No. & $\%$ & & \\
\hline \multicolumn{7}{|c|}{ SOF/DCV: } \\
\hline Yes & 1 & 14.3 & 101 & 34.4 & \multirow{2}{*}{$\begin{array}{l}\text { Fisher } \\
\text { test }\end{array}$} & \multirow{2}{*}{0.477} \\
\hline No & 6 & 85.7 & 192 & 65.6 & & \\
\hline \multicolumn{7}{|c|}{ SOF/LDV: } \\
\hline Yes & 2 & 28.6 & 110 & 37.5 & \multirow{2}{*}{$\begin{array}{l}\text { Fisher } \\
\text { test }\end{array}$} & \multirow{2}{*}{1} \\
\hline No & 5 & 71.4 & 183 & 62.5 & & \\
\hline \multicolumn{7}{|c|}{ OBV/PTV/r: } \\
\hline Yes & 2 & 28.6 & 47 & 16.0 & \multirow{2}{*}{$\begin{array}{l}\text { Fisher } \\
\text { test }\end{array}$} & \multirow{2}{*}{0.320} \\
\hline No & 5 & 71.4 & 246 & 84.0 & & \\
\hline \multicolumn{7}{|l|}{ SOF/VEL: } \\
\hline Yes & 2 & 28.6 & 36 & 12.3 & \multirow{2}{*}{$\begin{array}{l}\text { Fisher } \\
\text { test }\end{array}$} & \multirow{2}{*}{0.217} \\
\hline No & 5 & 71.4 & 257 & 87.7 & & \\
\hline
\end{tabular}

This table shows that there is no significant relation between type of DAA and HCC development. 


\section{DISCUSSION}

There was no statistically significant difference between the two studied groups as regard age, BMI or gender.

Our results are in agreement with study of Nahon et al. ${ }^{(7)}$ as they reported that there was no statistically significant difference between the studied groups as regard age, BMI or gender.

Kozbial et al. ${ }^{(8)}$ found that there was no statistically significant difference between the studied groups as regard age or gender.

The present study shows that $33.3 \%$ of HCC had history of treatment with surgical resection, $46.7 \%$ had history of RFA, $13.3 \%$ of TACE and $6.7 \%$ with liver transplantation. There is high significant difference between the two studied groups as regard ALT, total bilirubin and creatinine levels. Also there is significant difference between the studied groups as regard AFP while there is no significant difference between the two studied groups as regard albumin, INR, platelets, total protein and WBCs.

Our results are in line with study of Nahon et al. (7) as they reported that there was highly significant difference between the studied groups as regard ALT, AST and total bilirubin.

The increasingly widespread use of direct-acting antiviral agents (DAAs) has constituted a major breakthrough in the treatment of hepatitis $\mathrm{C}$ virus (HCV) infection, because of the high rates of sustained virologic response (SVR) achieved and an excellent safety profile ${ }^{(9)}$.

The current study shows that there was no significant difference between the studied groups as regard type of DAA used.

Our results are in agreement with study of Cardoso et al. ${ }^{(10)}$ as they reported that there was no significant difference between the studied groups regarding DAA used.

Our results show that there was no significant difference between the studied groups as regard chronic diseases.

Our results are supported by study of Nahon $\boldsymbol{e t}$ al. ${ }^{(7)}$ as they found that there was no significant difference between the studied groups as chronic diseases.

Calleja et al. ${ }^{(11)}$ studied patients receiving DAA agents outside of randomized, controlled trials and found similar rates of cure and frequency of side effects. DAA agents have been effective even in difficult-to-treat populations, including patients coinfected with HIV, patients with a liver or kidney transplant, and patients with end-stage renal disease.

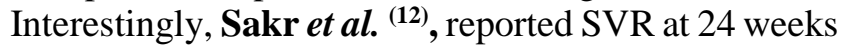
with DAA therapy plus ribavirin in a patient with mixed HCV genotype, which has been reported in patients with hemodialysis, intravenous drug use, and multiple transfusions.
Although DAA agents initially showed significant promise when first introduced to the market, subsequent studies noted a few limitations to these treatments. Researchers were particularly concerned over the possible increase in occurrence and recurrence of HCC noted in patients infected with HCV after SVR was achieved with DAA therapy. Of these patients, those with previous HCC were noted to have higher Child-Pugh scores, increased rates of liver stiffness and portal hypertension, and decreased platelet counts than those with no history of HCC ${ }^{(13)}$.

In the study in our hands, there is no significant difference between the studied groups as regard HCC occurrence or recurrence. There is no significant difference between the studied groups as regard Time needed for HCC to occur after DAA. There is no significant relation between type of DAA and HCC development.

Prenner et al. ${ }^{(14)}$ performed a retrospective study from 2014 to 2015 and compared patients treated with DAA therapy who either had active HCC on initiation or had previously received curative treatment for HCC with patients who had no history of HCC. Approximately $21 \%$ of patients with HCC failed to achieve SVR, which was significantly greater than the rate in those without $\mathrm{HCC}(12 \%)$. After multivariate analysis, the authors concluded that patients with active HCC upon initiation of DAA therapy were almost 6 times more likely to fail treatment, whereas those who had already received curative treatments for HCC showed SVR by 24 weeks after completion of DAA treatment. These findings led to further speculation as to whether the HCV/HCC interaction may have a more significant role than previously recognized ${ }^{(\mathbf{1 4})}$.

Reports investigating long-term effects of DAA therapy continued to question the effect of DAA agents on the occurrence of $\mathrm{HCC}$ in patients with $\mathrm{HCV}$ cirrhosis, especially in those with a history of HCC. This was initially highlighted in a study by Reig and colleagues that primarily focused on $\mathrm{HCV}$ patients who had achieved complete radiologic response (no identifiable tumors on imaging) after treatment for HCC with ablation, resection, or chemoembolization and subsequently underwent all-oral DAA therapy. Patients with a history of interferon therapy or with non-characterized nodules $(<10-\mathrm{mm}$, radiographically detectable lesions) were excluded. In this study, the authors noted HCC recurrence at a median of 5.7 months, with half of these recurrences characterized as multinodular and $20 \%$ having infiltrative or extrahepatic lesions ${ }^{(\boldsymbol{(})}$.

Further studies continued to question the role of $\mathrm{HCV}$ therapy on HCC recurrence. A meta-analysis of 11 studies of adjuvant therapy with interferon compared to DAA agents showed accelerated HCC recurrence at 6 months in the latter group ${ }^{(11)}$. More specifically, between $0 \%$ and $12.5 \%$ of untreated 
patients experienced HCC recurrence at 6 months, which was significantly less than the rate found in patients who received DAA therapy $(>28 \%)$. Patients with HCC recurrences were also noted to be younger (56 vs 73 years) and more frequently treatmentexperienced (88.2\% vs $61.9 \%){ }^{(11)}$.

Nagaoki et al. (16) noted reduced HCC development in patients with HCV genotype $1 \mathrm{~b}$ after achieving SVR and determined that such an impact was comparable to that of interferon-based therapy.

Muir et al. ${ }^{(17)}$ arrived at similar conclusions, noting that the incidence of de novo HCC was higher in patients with decompensated cirrhosis and in those who achieved SVR with pegylated interferon/ribavirin therapy, compared to those with compensated cirrhosis or who were treated with DAA therapy.

Not only have DAA agents increased treatment rates for chronic HCV infection, but they have also impacted the need for liver transplantation. In a cohort study for adults wait-listed for liver transplant, the rate of liver transplant wait-listing in the setting of decompensated cirrhosis secondary to HCV infection had decreased by $32 \%$ in the period of high DAA use, compared to a $5 \%$ reduction in the period of high pegylated interferon use ${ }^{(\mathbf{1 8})}$.

Although many studies have highlighted HCC recurrence after DAA therapy, some studies have suggested that there may be insufficient evidence for such a claim. The European studies that postulated an association between HCC recurrence and DAA therapy were noted to be mostly observational and were not randomized, controlled trials, which thereby allowed for possible confounding variables ${ }^{(\mathbf{1 9})}$.

Furthermore, Chokkalingam et al. (20) performed a retrospective study using claims data to evaluate the risk of incidence of HCC following sofosbuvir (Sovaldi, Gilead)-based therapy. Initially, the authors noted a higher HCC incidence in patients treated with DAA therapy compared to patients not treated with DAA agents. However, when adjusted for age, cirrhosis, and portal hypertension, the incidence rates of HCC appeared to show no difference between the 2 groups.

According to Nahon et al. ${ }^{(7)}$, there was increase in HCC incidence observed in patients with cirrhosis treated with DAAs compared with patients who achieved SVR following an IFN therapy can be explained by patient characteristics (age, diabetes, reduced liver function) and lower screening intensity.

An interesting manuscript by Lu et al. (21) showed data from a long-term follow-up for HCC detection in numerous HCV cohorts, including both patients who were treated with antiviral therapy and those who were not. The treated population was divided into patients who achieved an SVR and those who did not. The lack of SVR achievement emerged as a risk factor for HCC development. They also showed that an SVR reduced the risk of all-cause mortality in patients with advanced fibrosis. Innes et al. ${ }^{(22)}$ showed similar results, confirming that there is a higher risk of HCC occurrence after DAA therapy compared to IFN therapy.

Furthermore, Bielen et al. (23) did not find higher-than-expected early occurrence rates of $\mathrm{HCC}$ in patients treated with DAA regimens $(1.1 \%$; 4/355) compared to patients treated with IFN regimens (1.7\%; 1/59). These rates were comparable to the estimated $1 \%$ per year frequency of HCC that is observed in patients with an SVR who were treated with IFN and ribavirin dual therapy.

Regarding, Ioannou et al. ${ }^{(24)}$ recently published a study on 62,354 patients who received antiviral treatment in the Veterans Affairs National Healthcare system between $1 / 1 / 1999$ and $12 / 31 / 2015$. The study included 35871 (58\%) IFN-based regimens, 4535 (7.2\%) DAA+ IFN regimens and 21948 (35\%) DAAbased regimens. They identified 3271 incident cases of HCC diagnosed at least 180 days after initiation of the antiviral treatment over a mean follow-up of 6.1 years. The incidence of HCC was highest in patients with cirrhosis and who were experiencing treatment failure. SVR was associated with a significantly decreased risk of HCC (a $71 \%$ risk reduction) in the DAA-treated cohort.

\section{CONCLUSION}

The introduction of direct-acting antiviral agents (DAA), the rate of sustained virologic response (SVR) in the treatment of hepatitis C virus (HCV) has radically improved. Robust scientific evidence supports a beneficial role of SVR after interferon therapy in the progression of cirrhosis, resulting in a decreased incidence of hepatocellular carcinoma (HCC). However, a debate on the impact of DAAs on the development of $\mathrm{HCC}$ is ongoing.

For people at risk, it is noteworthy to explain the importance of continued surveillance after $\mathrm{HCV}$ eradication.

Also, physicians in the outreach clinics should know by heart that in HCV-positive patients, the risk of HCC is reaching higher figures compared with those eliminated the virus, yet sustained responders having advanced fibrosis are still at high HCC risk.

\section{REFERENCES}

1. Zanetto A, Shalaby S, Ferrarese A et al. (2018): Dropout rate from the liver transplant waiting list because of hepatocellular carcinoma progression in hepatitis $\mathrm{C}$ virusinfected patients treated with direct-acting antivirals. Liver Transpl., 23:1103-1112.

2. Burra P, Giannini EG, Caraceni $P$ et al. (2018): Specific issues concerning the management of patients on the waiting list and after liver transplantation. Liver Int., 38:1338-62.

3. Janjua NZ, Chong M, Kuo M et al. (2017): Long-term effect of sustained virological response on hepatocellular carcinoma in patients with hepatitis $\mathrm{C}$ in Canada. J Hepatol., 66:504-13.

4. Manns M, Samuel D, Gane EJ et al. (2016): Ledipasvir and sofosbuvir plus ribavirin in patients with genotype 1 or 4 hepatitis $\mathrm{C}$ virus infection and advanced liver disease: a 
multicentre, open-label, randomised, phase 2 trial. Lancet Infect Dis., 16:685-97.

5. Afdhal N, Reddy KR, Nelson DR et al. (2014). Ledipasvir and sofosbuvir for previously treated HCV genotype 1 infection. N Engl J Med., 370:1483-93.

6. Reig M, Mariño Z, Perelló C et al. (2016): Unexpected high rate of early tumor recurrence in patients with HCVrelated HCC undergoing interferon-free therapy. J Hepatol., 65:719-26.

7. Nahon P, Layese R, Bourcier V et al. (2018): Incidence of hepatocellular carcinoma after direct antiviral therapy for $\mathrm{HCV}$ in patients with cirrhosis included in surveillance programs. Gastroenterology, 155(5): 1436-1450.

8. Kozbial $\mathrm{K}$, Moser S, Schwarzer $\mathrm{R}$ et al. (2016): Unexpected high incidence of hepatocellular carcinoma in cirrhotic patients with sustained virologic response following interferon-free direct-acting antiviral treatment. Journal of Hepatology, 65(4): 856-858.

9. Pawlotsky JM (2014): New hepatitis C therapies: the toolbox, strategies, and challenges. Gastroenterology, 146:1176-1192.

10. Cardoso H, Vale AM, Rodrigues S et al. (2016): High incidence of hepatocellular carcinoma following successful interferon-free antiviral therapy for hepatitis $\mathrm{C}$ associated cirrhosis. Journal of Hepatology, 65(5): 1070-1071.

11. Calleja JL, Crespo J, Rincón D et al. (2017): Spanish Group for the Study of the Use of Direct-Acting Drugs Hepatitis C Collaborating Group. Effectiveness, safety and clinical outcomes of direct-acting antiviral therapy in HCV genotype 1 infection: results from a Spanish real-world cohort. J Hepatol., 66(6):1138-1148.

12.Sakr AA, Hanifi JM, Valerie LM (2017): Successful treatment of mixed hepatitis $\mathrm{C}$ genotypes in a cirrhotic patient with an all-oral, interferon-free regimen. ACG Case Rep J., 4:16-19.

13. Nault JC, Colombo M (2016): Hepatocellular carcinoma and direct acting antiviral treatments: controversy after the revolution. J Hepatol., 65(4):663-665.

14. Prenner SB, Van Wagner LB, Flamm SL et al. (2017): Hepatocellular carcinoma decreases the chance of successful hepatitis $\mathrm{C}$ virus therapy with direct-acting antivirals. J Hepatol., 66(6):1173-1181.
15. Buonfigioli F, Conti F, Andreone $P$ et al. (2016): Development of hepatocellular carcinoma in HCV cirrhotic patients treated with direct acting antivirals. Journal of Hepatology, 64: 215-220.

16. Nagaoki Y, Aikata H, Kobayashi $T$ et al. (2016): Development of hepatocellular carcinoma in patients with hepatitis C virus infection who achieved sustained virological response following interferon therapy: A largescale, long-term cohort study. J Gastroenterol Hepatol., 31(5):1009-15.

17. Muir A, Buti M, Nahass $R$ et al. (2016): Long-term follow-up of patients with chronic $\mathrm{HCV}$ infection and compensated or decompensated cirrhosis following treatment with sofosbuvir-based regimens. Hepatology, 64: 437-438.

18. Flemming J, Kim WR, Brosgart CL et al. (2016): Reduction in liver transplant wait-listing in the era of direct acting anti-viral therapy. Hepatology, 65(3):804-812.

19. Brown RS (2016): The possible association between DAA treatment for $\mathrm{HCV}$ infection and $\mathrm{HCC}$ recurrence. Gastroenterol Hepatol., 12(12):776-779.

20. Chokkalingam AP, Singer AW, Osinusi AO et al. (2016): Risk of incident liver cancer following HCV treatment with sofosbuvir-containing regimens. Hepatology, 64:365-366.

21.Lu M, Li J, Rupp LB et al. (2016): Hepatitis C treatment failure is associated with increased risk of hepatocellular carcinoma. J Viral Hepat., 23:718-729.

22. Innes H, Barclay ST, Hayes PC et al. (2018): The risk of hepatocellular carcinoma in cirrhotic patients with hepatitis $\mathrm{C}$ and sustained viral response: role of the treatment regimen. J Hepatol., 68(4):646-654.

23. Bielen R, Moreno C, Van Vlierberghe $H$ et al. (2017): The risk of early occurrence and recurrence of hepatocellular carcinoma in hepatitis C-infected patients treated with direct-acting antivirals with and without pegylated interferon: A Belgian experience. J Viral Hepat., 24:976-981.

24. Ioannou GN, Green PK, Berry K (2017): HCV eradication induced by direct-acting antiviral agents reduces the risk of hepatocellular carcinoma. https://www.ncbi.nlm.nih.gov/pubmed/28887168 